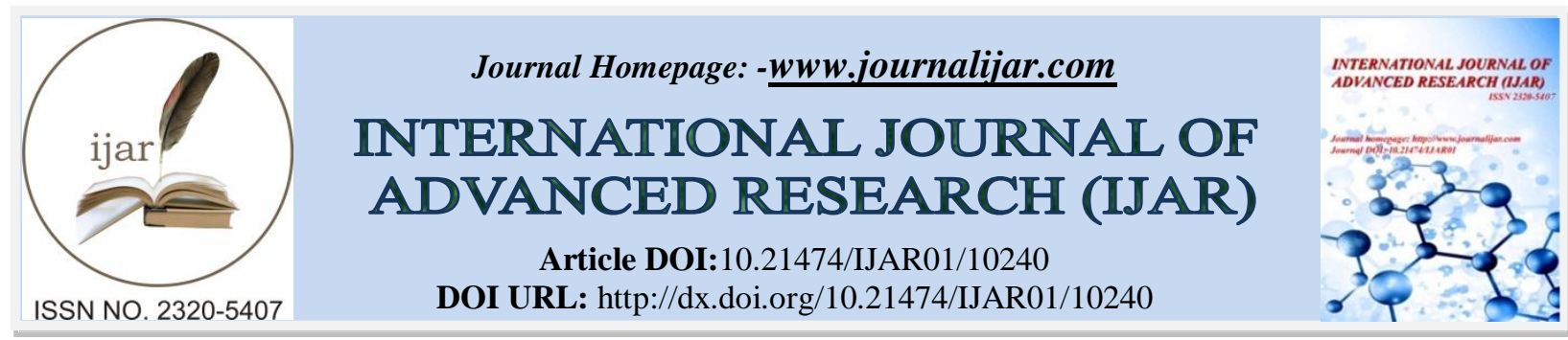

RESEARCH ARTICLE

\title{
ENFORCEMENT OF ELECTION ETHICSFOR THE DEVELOPMENT OF THEINDONESIAN DEMOCRACY (A DIGNIFIED JUSTICE PERSPECTIVE)
}

\section{Dr. Jeferson Kameo SH. LLM ${ }^{1}$ and Prof. Dr. Teguh Prasetyo SH. M. Si ${ }^{2}$}

1. Assistant Professor in Law at the Faculty of Law, Universitas Kristen Satya Wacana Salatiga-Indonesia.

2. Professor of Law, Faculty of Law Universitas Pelita Harapan, Karawaci-Indonesia and Commisioner of the DKPP-RI.

\section{Manuscript Info}

\section{Manuscript History}

Received: 12 October 2019

Final Accepted: 14 November 2019

Published: December 2019

Key words:-

Enforcement, Ethics, Development,

Democracy, Pancasila, Dignified Justice

\begin{abstract}
There are prominents functions of a Theory. Among others, is the function to help people (the jurists) in understanding and explaining or justifying, and possibly also the falsification of a legally wide range of problems in human life in a society, a nation and a state. This research article has been written as a result of an effort trying to grasp the meaning of democracy in the Indonesian politics from the perspective of a what so called a new philosophy of law or jurisprudence, the Indonesian Jurisprudence. These authors would argue that the enforcement of the Electoral Organizers Ethics by the Election Organizers Honorary Council of the Republic of Indonesia (DKPP-RI) should be seen as an indication or manifestation of the developing Indonesian democracy. In the Indonesian Volksgeist, this institution (DKPP) have been equiped with tasks to handling violations of the code of ethics by the General Election Organizers. From the perspective of Dignified Justice Jurisprudence, this search has found that according to the General Election Law (Law No. 7 of 2017), the DKPP-RI is part of the institutions that carry out general elections in Indonesia. This unique institution has been strengthened and clarified. The duties and functions of DKPP have been adjusted to the development of legal needs in the holding of general elections. The institutional strengthening of the Election Organizer have been intended to be able to create a clear, systematic and democratic election, as mentioned above; a form of implementation to develop democracy in the Indonesian politics.
\end{abstract}

Copy Right, IJAR, 2019,. All rights reserved.

\section{Introduction:-}

This research article has been written as a result of an effort trying to grasp the meaning of democracy in the Indonesian politics from the perspective of a what so called a new philosophy of law or jurisprudence, the Indonesian Jurisprudence. In this view, it appears that it might had been a little bit daunting task. In achieving such an aim, these authors is using or utilising a new legal theory that have been developed in Indonesia, namely the

Corresponding Author:-Dr. Jeferson Kameo

Address:-Assistant Professor in Law at the Faculty of Law, Universitas Kristen Satya Wacana SalatigaIndonesia. 
theory of Dignity Justice (Dignified Justice theory) ${ }^{1}$. It is therefore necessary in the first place to briefly describe the Indonesian Jurisprudence or legal theory.

\section{A Brief Account on the Dignified Justice Jurisprudence:}

As has been quite a widely known, the theory of Dignified Justice or the Dignified Justice Jurisprudence is a legal theory ${ }^{2}$. It is an Indonesian homegrowntheory of law, or the Indonesian science of law (legal science) or legal philosophy. This Theory have often been abbreviated with Dignified Justice. There are prominents functions of this Theory. Among others, is the function to help people (the jurists) in understanding and explaining or justifying, and possibly also the falsification of a legally wide range of problems in human life in a society, nation and a state.

Including, in this activity, understanding and explaining how the enforcement of election organizers ethicts within the law for the development of the indonesian democracy to be a dignified democracy or election, as a form of spelling the indonesian politics in realizing democracy. As a legal theory, the theory of Dignified Justice has a number of postulates or beliefs in the important field of legal science. Just in passing, in order to understand what a theory of Dignified Justice is, in the following, these authors has put forward some of the quite a lot of scientific beliefs (postulates) in the systemic theory of Dignified Justice. As pointed out above, some of the postulates are expressed herewith as far as they are used to understand and explain the problem (issues) addressed.

Firstly, according to the Dignified Justice, it is stated that if people (jurists) want to find the law, then the law should be sought in the soul of the nation (Volksgeist). Intended by Volksgeist, according to the perspective of Dignified Justice $^{3}$, namely the applicable laws and regulations and also court decisions (judge-made laws). It is hoped that what which is examined and studied should be the court decisions in a jurisdiction in question, which have permanent legal force.

This theory have been discovered and originally developed by one of the author of this Research Article, i.e. Professor Teguh Prasetyo. There have already been many books and journals (National and International), including in this international journal the publications and disseminations of this theory internationally. Some books that contain the theory of Dignified Justice can be read for example, among many from: Teguh Prasetyo, Dignified Justice: Perspective of Legal Theory, First Printing, Nusa Media, Bandung, 2015; Legal Reform: Perspectives on Dignified Justice Theory, First Printing, Setara Press, Malang, 2017; Pancasila Legal System ( System, Legal System and the Formation of Laws and Regulations in Indonesia): Perspective of Dignified Justice Theory, First Printing, Nusa Media, Bandung, 2016; The General Election Philosophy, First Printing, Nusa Media, Bandung, 2019; Dignified Election (Reorientation of New Thoughts about Democracy), First Printing, by RajaGrafindo Persada, Depok, 2017.

As a Dignified Justice Theory is not the definition of a type of justice, but Dignified Justice theory is a name of legal theory/legal science. The theory of law or theory of law is essentially the same as the philosophy of law (philosophy of law or legal philosophy), as well as jurisprudence or legal science and legal science. At present, in all Law Faculties throughout Indonesia there is only one Study Program, namely the Study Program in Legal Studies, not State Administration Law, Criminal law, Civil law, International Law and others, but Legal Science or jurisprudence. Ideally, because in all the Law Faculties in the country there is currently only one study program, the Law Study Program, it is no exaggeration if the Dignified Justice theory needs to get the attention of serious legal scientists (jurists) in explaining and understanding the law. Sultan Agung Islamic University Semarang, places the theory of Dignified Justice as the subject of a separate subject in its Doctor of Law program. At present, a Bachelor of Law, especially a Masters and Doctor of Law must master Jurisprudence, such as mastering the Indonesian Jurisprudence, the Dignified Justice Theory. With the current Law Study Program throughout Indonesia, a Jurist must have the mastery and ability to study all branches of law such as Civil Law, Criminal Law, State Administration and Law, International Law, Business Law, Labor Law, Cyber law or Telematics and so forth from the shrinkage of view of law, Theory of law or Jurisprudence. Therefore, the mastery of a Legal Theory is very strategic.

There is also the concept of Volksgeist according to the famous German philosopher, von Savigni. Although, the nature and the meaning or understanding of the concept of nation from von Savigni is different from the meaning that is understood in Dignified Justice. 
Secondly, in the perspective of Dignified Justice, the purpose of the law, including what is sought within, is the truth in the form of dignified justice. The concept of dignified justice is well known as justice which humanizes humans (nguwongke uwong). Such justice is found in every sould of every nations Volksgeist civilized, particularly those sourced from the Pancasila as the source of all sources of law in Indonesia, namely the Pancasila Legal System ${ }^{4}$. Intended with numanizes human beings as the principle truth (the truth), the purpose of the law, is embodied in the image of justice with dignity, and which contains justice itself, benefits (utilities) or fairness, and certainty. What is written in the laws and regulations applicable and used by judges in delivering justice, then that is true; meaning fair, and useful with certainty; like the sun that always rises in the East.

The Dignified Justice does not contradict or antinomize between truths in the form of justice versus expediency or justice versus legal certainty or expediency and certainty and so on. In the Dignified Justice, what is just, that is, what is found formulated in the Volksgeist, as stated above. It is also what is beneficial (fairness), as well as certain. The law, which is in the soul of the nation ${ }^{5}$, is Civil Jurisdiction that manifests and applies, exists or is held to ensure the availability of truth in the form of justice that humanizes humans, namely justice in which there is justice itself, expediency and certainty.

That truth must always be there, in the Civil Jurisdiction and can be cultivated, can be achieved in the perspectife of Dignified Justice, namely what is called justice which humanizes humans. It is also important to note that justice that humanizes humans is not a truth that is an ideological ideal ${ }^{6}$, it is not an ideological propaganda from a or whatsoever regime(s) that wanted to maintain its power. However, justice which humanizes humans is a business and the result of the efforts of rational human beings, nobles creatures created by the God Almighty ${ }^{7}$ in Pancasila as the State Foundation, the source of all sources of law. Thus, justice that humanizes human beings (nguwongke uwong) is not an utopia, an ideology and hollow reverie, even many times destructive. Not a meta-juridical but the juridical. It is said juridical because the truth in the form of justice, benefit and certainty must be implemented, workable, can be achieved while human and rational (juridical) society exists or exists on earth, under this sky, especially in the Pancasila Legal System.

See, an explanation of the Pancasila Legal System, in: Teguh Prasetyo, the Pancasila Legal System ( System, Legal System and Formation of Laws and Regulations in Indonesia), Perspective of Dignified Justice Theory, First Matter, Nusa Media, Bandung, 2016.

Must be sought within the soul of the nation, not outside the soul of the nation. Intended outside the soul of the nation, is the soul of another nation as in theories developed by experts in the Western world. Because, if the search for law is found outside the soul of the nation, then the effort is not dignified; except, and this is also a postulate known in the Dignified Justice theory, the researcher or answer seeker or the law is willing to do a comparison (comparative study). Dignified Justice Theory is not a chauvinistic, and anti-foreign theory. On the contrary, the theory respects the existence of a legal yam societas ibi ius, that law is everywhere in civilized nations or societies .

Humanitarian civilized, a key pillar in the human effort in a rational society to humanize humanbeings (nguwongke uwong) it should not be seen as an ideology (ideology) or an ism; an indication of political propaganda that only wants to perpetuate power. Because ideology is utopia, just a mere ideals. An aspiration that if unachievable, grasp or afforded and held by the already determined to carry it out, then it does not matter; there are no sanctions and cannot be forced. On the contrary, civilized humanity is a juridical formula; a first agreement of a nation, an agreement. The agreement is a law for those who make it, thus, must be implemented. If not implemented, it is a violation of the agreement; something shameful. Because it is a violation, its implementation can be imposed by a State instruments. This is a general legal principle which is recognized all of the civilized worlds. Likewise, as a juridical formula, civilized humanity must be managed by those who are determined to do it. If nothing can be attempted, then those who promise/swore to carry it out (generally politicians in Political Campaigns) will receive legal (political) sanctions, forced to carry it out according to applicable law. Instead, insisting on an ideal to be implemented is a violation of human rights, a "step" that cannot be accepted by civilized and rational people.

The Judge in Indonesia and around the world, are the ones who often greeted with calls Majesty (Your Honor). A fact, which is everywhere, is not a utopia. Legal education is carried out, financed by the State and Society, even by individuals to ensure the existence of their Noble 


\section{DKPP the Ethics Court for Dignified Justice Elections:}

If the philosophy of Dignified Justice, as briefly accounted for above should be use to justify the democracy in the Indonesian politics; these authors would argue that the enforcement of the Electoral Organizers Ethichs by the Election Organizers Honorary Council (DKPP) should be seen as an indication or manifestation of the developing Indoneian democracy. In the Indonesian Volksgeist, this institution (DKPP) have been equiped with tasks to handling violations of the code of ethics by the Election Organizers ${ }^{8}$. Now, this institution has become an important factor, unique in the wold, in the organization of Election Organizers according to the Indonesian Volksgeist, or the Indonesian Election Law. DKPP has been considered as a Joint Commission of the National Election Supervisory Body in accordance with the Indonesian Constitution to contribute to the development of democracy or the Indonesian politics, making the Elections and Democracy in Indonesia as a Dignified Election or Dignified Democracy ${ }^{9}$.

From the perspective of Dignified Justice, the search has found that according to the Election Law (Law No. 7 of 2017), the DKPP-RI is part of the institutions that carry out elections. This unique institution has been strengthened ${ }^{10}$ and clarified. The duties and functions of DKPP have been adjusted to the development of legal needs in the holding of general elections. The institutional strengthening of the Election Organizer is intended to be able to create a clear, systematic and democratic election, as mentioned above, a form of implementation to develop democracy in the Indonesian politics.

This means that during this time of efforts taken to understand or justify the Politics in Indonesia, including that carried out prior to the establishment of new the election law, as mentioned above; there have been sproblems in the institutional aspects of Election in Indonesia. Examined closely, the problems have been existing in the various Election Laws that were previously in force. All previous laws have contributed to unsystematic and undemocratic implementation of the Election from time to time.

As stipulated above, DKPP-RI as part of the Constitutionally Election Body, and in the context of this paper as part of Indonesian politics in develping democracy is a the national capital. DKPP was formed to examine and decide complaints and/or reports of alleged violations of the code of ethics ${ }^{11}$. The alleged violation of the code of ethics reported and reported was allegedly carried out by: (1) members of the General Election Commision (KPU), (2) members of the Provincial KPU, (3) members, Regency/City KPU, (4) Members of the Supervisory Body of General Election (Bawaslu), (5) members of Provincial Bawaslu and (6) members of Regency/City Bawaslu.

Just a comparison $^{12}$, firstly, before the comming into force ot the General Election Act, under the provisions of Article 109 paragraph (2) of Law No. 15 of 2011 on General Election, which has been replaced by the New Election

Article 1 number (24) of Law no. 7 of 2017 concerning the Indonesian General Elections (Election Law).

Generally Law Elections as a manifestation of the most concrete of the Volksgeist in the field of general elections in Indonesia not only set the ethics of institutional election organizers alone, the Election Law also regulates the institutional election, institutional violations of electoral and institutional dispute in the Election, and resolving any criminal acts conducted within any Elections in the Civil Jurisdiction of Indonesia.

The term used, i.e. to strengthen the Election Law could be interpreted as a self-criticism of the institution of the Honorary Board for the Election Organizers Commission in 2008. The Commission argued that the previous Commission has been formed as the forerunner of DKPP with the Law Number 22 of 2007 concerning Election Organizers to resolve issues of violation of the code of ethics for election organizers. At that time, it was felt that the prior National Election Organizer (the Old KPU) authority was not so strong, since the institution was only functioned to summon, examine, and hear, giving recommendations to the KPU and was ad hoc. Jimly Asshiddiqie, (2014), Upholding Election Organizer Ethics, RajaGrafindo Persada, Depok, p., Vii.

Article 155 paragraph (2) of the Election Law. The phrase "accept and decide" are two characteristics of a judicial institution; therefore DKPP is called a court of law, because it receives and decides complaints and/or reports of alleged violations of the code of ethics within the Law.

Comaparive law analysis like this can be found in the method in Esin Örücü, The Enigma of Comparative Law: Variations on a Theme for the Twenty-First Century, Martinus Nijhoff Publishers, Leiden/Boston, p. 93-102, 
Law, one of the authority of DKPP was to examine, hear, and decide on complaints and/or reports of alleged violations of the code of ethics committed by members in the fifteen institutions involved in organizing elections. The fifteen institutions are the KPU, Provincial KPU, Regency/City KPU, PPK, PPS, PPLN, KPPS, KPPLSN, and the Aceh Independent Voter Commission (KIP) and their ranks in the district/city, and Bawaslu, Provincial Bawaslu, and Regency/City Panwaslu, District Election Supervisory Committee, Field Election Supervisor, and Overseas Election Supervisor.

Seen from a comparative study of Indonesian Volksgeist, namely between the Election Laws and the Election Organizer Acts that has been revoked and declared invalid with the New Election Law, there was a phrase, "to adjudicate", in the Article 109 of paragraph (2) of Law No. 15 of 2011 concerning Election Organizers . The old concept was no longer emerging in the New General Election Law. However, this does not cause DKPP as no longer having a judicial power to deliver justice. Because the phrase "receive and decide", has been included in the definition check, to mean adjudicated, and decide according to the law. The issue here is merely about the efficiency of using words.

Considering fairnes in the New General Election Law, it is worth mentioning here that the notion of justice can be found in this soul of the nation as well, that is, can be found in the doctrines taught by Indonesian jurists. According to Sudikno Mertokusumo:

the word judicial consists of the basic word "fair" and gets the prefix "per" and the suffix "an", means everything related to the court. The court here is not interpreted solely as a body of trial, but as an abstract sense, that is "delivering justice". "Matters of giving justice" means: those which relate to the duty of a court or judge in delivering justice, that is, giving to the person concerned-concretely to those who ask for justice-what is his right or law. In a judge or court giving the person concerned about what their rights or laws are the court will always used or based on the applicable law in considering wether an action does not implement and maintain the law or guarantee compliance with material laws, before making decisions ${ }^{13}$.

It can be seen from the definition of court as mentioned above that the presence or absence of the verb "to adjudicate", that has been found in Article 109 paragraph (2) of Law Number 15 of 2011 concerning Election Organizers and no longer found in the the New General Election Law cannot be used as a determining factor for no longer considering DKPP as not having a judicial capacity as a court of ethics according to the law.

The most important thing from the definition of justice is that it provides justice, and other elements as seen in the above definitioned. In the concept of justice, the next meaning that is no less important is the implementation and retention of the law or guaranteed compliance with material laws, including in this case the Decision of the DKPPRI. Material law that is maintained by DKPP, namely ethical values that have been determined in DKPP Regulation No. 2 of 2017. Therefore it could be argued that factually, DKPP indeed decides cases with justice, whose function is to position the defendants according to their actions and that is also why DKPP is referred to as ethical justice according to law. Sice it is according to the Law Number 7 of 2017 (of the what so called the New Indonesian Election Law).

Construction of DKPP as a judicial ethics (court of ethics) should be reformed as judicial ethics by law (the court of ethics According to the law). The first concept can connote general ethical justice, which is subjective and arbitrary, which does not have binding power and can be enforced by the state apparatus. Meanwhile, in the construction of judicial ethics election organizers according to the law, then DKPP is in it is the judiciary power, that is running according to the applicable law, and generally applicable and enforceable with sanctions already in specified in the regulations for breach of ethics proven.

The function of DKPP according to the Genegal Election Law, or in the perspective of Dignified Justice, which according to the most concrete manifestation of it in the Volksgeist derived from Pancasila is to to preserve at least

with the concept of internal transposition. Also compare the legal comparisons in Teguh Prasetyo, Legal Research Methods in the Perspective of Dignified Justice Theory, First Printing, Nusa Media, Bandung, 2019.

Sudikno Mertokusumo, History of the Judiciary and Its Laws in Indonesia Since 1942 and What Their Benefits Are for Us Indonesians, Second Printing, Liberty, 1983, Yogyakarta, pp. 2-3. 
three values ${ }^{14}$. This function can be said as a function to maintain the purity of values-the function of values within the law for the Election Organizer institutional.

Ethics violation is seen as a violation of values. Election organizers are required to always have purity of values. Ethical violations are considered as value violations if the Election Organizer cannot behave in the conduct of an Election in accordance with the existing values, detailed in the DKPP Regulations as stated below, then the person/organizer of the Election will be subject to sanctions, because the behavior is not in line, not matches the purity of values required for the organizer of the election. The termination sanction, for example, cannot be interpreted as termination of employment, but it is an act of purifying values by removing the Complained/Reported Party from the Election organizing group who must oversee the purity of the Election Implementation value ${ }^{15}$.

The following are values according to law (DKPP Regulation No. 2 of 2017) as intended above. The first value, which is the value of independence. The second value, namely integrity, and the third value, credibility. It is clear here, that in the Election Law there has been a development, or reconciliation and explanation in the form of virtues found in justice with dignity, namely independence. Previously only two values were mentioned, namely credibility and integrity and have been widely discussed.

Strengthening and explaining these values shows that there is a clear difference between a dignified election and the values contained therein. Dignity is far greater than the value of independence, credibility and integrity. Because the three values are clearly seen as under umbrella by dignity. Thus in the perspective of the Election Law as the most concrete manifestation of justice for dignity, then an Election with dignity is broader than an Election that fights or enforces social values that are incorporated into legal values such as independence, let alone just fighting for social values in law such as integrity and credibility and various other values that can still be further explored in the General Election Law. Dignity is related to obedience to all legal values that apply in the Volksgeist.

For such a task DKPP has the authority to summon whistleblowers, witnesses, and/or other parties concerned for questioning, including, for questioning of documents or other evidence; impose sanctions on election organizers who are proven to have violated the code of ethics; and decide on violations of the code of ethics. As part of their duties, the DKPP can also form a regional inspection team or TPD in each province that is ad hoc . T PD each of four people. The provisions regarding the duties, functions, authority, and work procedures of the regional inspection team are regulated by DKPP Regulations ${ }^{16}$. Like DKPP, TPD must applying the principles of maintaining justice, independence, impartiality, and transparency; enforce ethical norms or norms that apply to General Election Administrators ; being neutral, passive, and not making use of cases that arise for personal popularity; and deliver decisions to related parties to be followed up ${ }^{17}$.

In the context of the discussion of values, ethics is the study of values, which is value as something that is considered good and right by a society in a place, and in a certain period of time. However, such an understanding of ethics is an ethical ontology in general, not ethics in a juridical ontology. From the perspective of juridical onology, common ethical values do not have forced power by the State. There is a slight difference notion, but significant with ethical in juridical ontology. Because the values described here are legal ethical values, or positive ethics. Violations of juridical ethics can be rewarded with legal sanctions and imposed by mutual agreement, as well as by the State. To further study of ethics in general, read books written by the most qualified ethicists in the field, written by Franz Magnis-Suseno, Political Ethics: Basic Moral Principles of Modern State, Third Matter, Gramadia Pustakan Utama, Jakarta, 1991; or Franz Magnis-Suseno, Philosophy as Critical Science, Second Printing, Kanisius, Jakarta, 1993.

Quoted from the view of the Chairman of the DKPP-RI, Dr. Haryono, SH, MCL, in a discussion entitled: DKPP Decision Format, Thursday, October 27, 2017, at the Lor In Hotel, Sentul, Bogor.

Article 164 of the Election Law. The author can report, even though this is only a personal opinion and does not represent DKPP's view as an institution, the TPD will be given the task to carry out actions that are pre-investigation and pre-verification of reports that come to D of the KPP.

${ }^{17}$ Article 159 of the Election Law. 
To carry out its duties and functions in upholding the Election Organizer's code of ethics, DKPP forms the DKPP Regulations and determines DKPP decisions ${ }^{18}$. Further provisions regarding the procedures for carrying out DKPP duties are regulated in the DKPP Regulations. In the event that DKPP forms the DKPP Regulation, DKPP is required to consult with the Parliament or DPR and the Government through a hearing ${ }^{19}$.

Regarding the principle of professionalism as an ethical guideline for Election Administrators, a number of legal values have been determined, namely: (1) legal certainty, (2) accessibility, (3) thinning, (4) open, and (5) proportional, (6) effective, (7) ) efficient and (8) public interests. The principle of legal certainty means that in the administration of elections, it must be carry out with the duties, functions and powers in accordance with the provisions of the laws. This principle reiterates that the ethical values applied to facts submitted to DKPP are ethical values according to the law or the rule of law, not the rule of ethics, that is, the rule of ethics according to the law . This principle contains the legality principle (the principle of 1 e gality).

While the principle of accessibility of meaningful conveniences supplied Election for disabel persons in order to achieve equality of opportunity. This principle again reveals the substance of the degree of equality or equality before the law and respect for human rights. Order means that in the administration of elections, it mus be carred out the duties, functions and powers in accordance with the legislation. This is the principle of law and order, which is also widely known in law. Openess means the administration of elections, organizers of Election gives access to the widely public disclosure. All of these principles are the Dignified Justice principles foundin Law No. 14 of 2008 concerning Openness of Public Information (LNRI Year 2008 No. 61. TLN RI No. 4846).

Regarding the principle of proportionality, it has been interpreted that in the administration of elections, the Election Organizers maintains a balance between personal interests and the public interest to realize justice. For the principle of rofesional means that in the administration of elections, the Operator Election understand the duties, powers and obligations to be supported expertise on dasa $\mathrm{r}$ pengetahua $\mathrm{n}$, skill, and insight.

The principle of effectiveness, means that in the administration of elections, Election Organizers organizing Elections are carried out according to the planned stages in a timely manner. Whereas eficient means that in the implementation of elections, the Organizers must be using the resources accordingly. The last principle in professionalism, namely the public interest. This value contains the meaning that in the implementation of the General Election must be aspirational, accommodating, and selective.

\section{Conclusion:-}

What the authors has described above should be regarded as the picture of the enforcement of the principles of ethics for the General Election Administration. That this enforcement of the principles of ethics is a form of an effort in the Indonesian politics to a developing of democracy according to its Volksgeist. As a result this enforcement of the ethical principles by the DKPP must also be considered as a form of a manifestation of Dignified Democaracy in the Indonesian Politics. As noted above, the theory of Dignified Justice as a legal science or philosophy of law, has been used in this article to explain and justify the Enforcement Ecthical Conduct in General Election as a form of delivering Democracy in the country.

If politics is power (power), and includes the power of the administration of elections to form, and when it needs to maintain control of the Government of a State, then in the perspective of Dignified Justice, which is intended to includes the form and involvement of DKPP -RI in order to ensure that they are given the power to hold elections as a process of formation or attempt to retain power is executed in accordance with the ethical principles that have been determined in the Indonesian Volksgeist, especially on ethical principles in the General Election Law and various implementing regulations that apply, specifically those relating Election Administrators.

\section{Bibliographies:-}

1. Asshiddiqie, Jimly. Menegakkan Etika Penyelenggara Pemilu, RajaGrafindo Persada, Depok, 2014;

Article 159 of the Election Law. Article 161 of the Election Law. 
2. Örücü, Esin. The Enigma of Comparative Law: Variations on a Theme for the Twenty-First Century, Martinus Nijhoff Publishers, Leiden/Boston;

3. Suseno, Franz Magnis. Etika Politik: Prinsip-prinsip Moral Dasar Kenegaraan Modern, Cetakan Ketiga, Gramadia Pustakan Utama, Jakarta, 1991; atau Franz Magnis-Suseno, Filsafat Sebagai Ilmu Kritis, Cetakan Kedua, Kanisius, Jakarta, 1993;

4. Sudikno Mertokusumo, Sejarah Peradilan dan Perundang-Undangannya di Indonesia Sejak 1942 dan Apakah Kemanfaatannya Bagi Kita Bangsa Indonesia, Cetakan Kedua, Liberty, 1983, Yogyakarta;

5. Teguh Prasetyo, Keadilan Bermartabat: Perspektif Teori Hukum, Cetakan Pertama, Nusa Media, Bandung, 2015;

6. _ Sistem Hukum Pancasila (Sistem, Sistem Hukum dan Pembentukan Peraturan PerundangUndangan di Indonesia): Perspektif Teori Keadilan Bermartabat, Cetakan Pertama, Nusa Media, Bandung, 2016;

$7 . \quad$ Pembaharuan Hukum: Perspektif Teori Keadilan Bermartabat, Cetakan Pertama Setara Press, Malang, 2017;

8. , Pemilu Bermartabat (Reorientasi Pemikiran Baru tentang Demokrasi), Cetakan Pertama, RajaGrafindo Persada, Depok, 2017;

9. _ Filsafat Pemilu, Cetakan Pertama, Nusa Media, Bandung, 2019;

10. Metode Penelitian Hukum dalam Perspektif Teori Keadilan Bermartabat, Cetakan Pertama, Nusa Media, Bandung, 2019. 